\title{
POLA PELAKSANAAN PENDIDIKAN KARAKTER DI SEKOLAH DASAR INSAN TERATAI TANGERANG
}

\author{
Mulyana \\ STABN Sriwijaya \\ mulyanawahyu45@gmail.com
}

\begin{abstract}
This study Aimed to describe the pattern of implementation of character education in Insan Teratai elementery school Tangerang. The method which used in this research is descriptive qualitative. In this study, the data collection techniques are observation, interviews, and documentation. The data is Analyzed using an interactive models of Miles and Huberman. The test of the data validity are using credibility, transferability, dependability, and confirmability. The conclusion of this research are: (1) The pattern of implementation of character education in Insan Teratai primary school is packed Penanaman Nilai Kemanusiaan (PNK) which has five core values, namely: truth, peace, love, right conduct, and non-violence; (2) The implementation of character education in Insan Teratai elementary schools divided into two activities: (a) in the classroom that is integrated into all subjects and (b) outside the class the which includes all activities, both routine and periodically, such as: silent sitting, praying together, story telling, eat together, commemoration national day, religious commemoration day, flag ceremony, Extracurricular (Marawis and Read Write Koran to Muslim students, Scouts, Futsal, English Club, Science Club, Math Club, Chinese Club, Art Club, Sepak Takraw, Angklung, Traditional Dance, and Drum Band), field trips, integration class, gardens, and spiritual guidance; (3) The role of parents in the implementation of character education in Insan Teratai elementary school are: actively participating in parenting, striker cleanliness, cleaning duties, recycling, and some help in the school kitchen; (4) Obstacles faced by the school until today, are: teachers' understanding of PNK has not been the same, every year there are teachers who enter so that should give you an understanding of PNK from the begining., not all teachers practiced PNK, understanding parents of PNK still lacking, parents support to PNK program at home is not maximized, some teachers still have difficulty connecting with PNK learning materials, students background are different, the pattern of education in different families, and guide the implementation PNK unclear; and (5) The challenges that faced by the schoolare: the public's understanding of the character education is still lacking, PNK is a program that always evolving and dynamic, optimization of the role of parents in supporting program PNK, student activities in school long enough for the elementary students, socialization PNK program to the community, especially parents, and the process takes a long time so that the results are not Immediately appears.
\end{abstract}

Keywords: Character, education, pattern. 


\section{Pendahuluan}

Sekolah merupakan lembaga pendidikan formal yang memegang peran strategis dalam mewujudkan amanat UU No. 20 Tahun 2003 tentang Sistem Pendidikan Nasional, yaitu menghasilkan lulusan yang berahlak mulia, jujur, berkualitas, demokratis, dan memiliki kemampuan untuk menghadapi tantangan dan persaingan global yang tidak dapat dihindari. Tujuan tersebut diperkuat kembali melalui pada PP No. 17 tahun 2010 berkenaan dengan tujuan pendidikan pada satuan pendidikan SD yang menekankan pada berbagai aspek, seperti beriman dan bertakwa kepada Tuhan Yang Maha Esa, berakhlak mulia, berkepribadian luhur, berilmu, cakap, kritis, kreatif, inovatif, sehat, mandiri, percaya diri, toleran, peka sosial, demokratis, dan bertanggung jawab. Hal ini mengisyaratkan bahwa keberhasilan pendidikan pada jenjang yang lebih tinggi sangat bergantung pada pondasi yang dibangun pada tingkat di bawahnya. Selain itu, proses pembentukan karakter merlukan proses yang sangat panjang, dimulai sejak bayi di lingkungan keluarga dan dilanjutkan di sekolah serta masyarakat.

Untuk menghasilkan lulusan yang memiliki kualitas yang dapat diandalkan dan memiliki moralitas atau watak (karakter) terpuji, sekolah harus mampu mengintergrasikan nilai-nilai kebaikan (virtues) dalam setiap aktivitas peserta didik di sekolah. Aktivitas peserta didik di dalam kelas maupun di luar kelas harus dapat dimanfaatkan dalam upaya menanamkan nilai-nilai kebaikan, sehingga akhirnya dapat menginternalisasikan dan mengaplikasikannya dalam kehidup sehari-hari.

Pada kenyataannya, belum banyak sekolah yang secara sungguhsungguh mengupayakan penanaman nilai-nilai karakter. Banyak sekolah yang melaksanakan pendidikan karakter hanya karena kurikulum mewajibkannya, sehingga langkah-langkah nyata belum diwujudkan secara konkret. Fenomena yang menghawatirkan pada remaja, seperti tawuran, penyalahgunaan narkoba, minum minuman keras, hubungan seksual pranikah, dan tindakan kriminal merupakan beberapa contoh belum efektifnya pendidikan karakter di sekolah.

SD Insan Teratai merupakan sekolah yang didirikan oleh orang-orang yang mendedikasikan dirinya di dunia pendidikan. Keperihatinan pendidikan di Indonesia telah menginspirasi untuk menciptakan generasi muda yang berakhlak mulia tanpa mengesampingkan kemampuan akademis. SD Insan Teratai berupaya memberikan pendidikan nilai karakter di dalam seluruh aktivitas sekolah melalui penanaman nilai-nilai kemanusiaan (PNK) untuk menciptakan peserta didik yang cerdas dan memiliki karakter mulia. PNK merupakan program unggulan yang diusung oleh SD Insan Teratai. Sekolah juga memberikan kesempatan kepada peserta didik dengan kemampuan ekonomi rendah dan tidak membedakan suku, ras, dan agama.

SD Insan Teratai sebagai sekolah yang baru berumur belum genap 4 tahun, masih ada berbagai kekurangan yang perlu diperbaiki disamping program-program unggulan yang ditawarkan. Penataan sumber daya 
manusia, penyamaan persepsi mengenai pendidikan karakter, dan pola pelaksanaannya merupakan bebrapa hal yang perlu dikelola dengan baik sehingga pendidikan karakter menjadi lebih terarah dan memberikan hasil secara efektif dan efisien. Dengan alasan tersebut, maka penelitian ini ditujukan untuk mendeskripsikan pola pelaksanaan pendidikan karakter di sekolah tersebut.

\section{Kajian Teori \\ Pengertian Pendidikan}

UU No. 20 tahun 2003 tentang Sistem Pendidikan Nasional bab I pasal 1, mendefinisikan pendidikan sebagai usaha sadar dan terencana untuk mewujudkan suasana belajar dan proses belajar agar peserta didik mengembangkan potensi dirinya untuk memiliki kekuatan spiritual keagamaan, pengendalian diri, kepribadian, kecerdasan dan ketrampilan yang diperlukan dirinya, masyarakat, bangsa dan negara. Dalam definisi tersebut, pendidikan merupakan usaya yang terencana oleh orang dewasa untuk merancang suasana dan proses pembelajaran sehingga peserta didik dapat belajar secara optimal. Fuad Ihsan (2010: 5) merangkum pengertian pendidikan sebagai: (1) suatu proses pertumbuhan yang menyesuaikan dengan lingkungan; (2) pengarahan dan bimbingan yang diberikan kepada anak dalam pertumbuhannya; (3) suatu usaha sadar untuk menciptakan suatu keadaan atau situasi tertentu yang dikehendaki masyarakat; dan (4) suatu pembentukan kepribadian dan kemampuan anak dalam menuju kedewasaan.

\section{Pengertian Karakter}

Secara umum, karakter dapat dimaknai sebagai sifat, keperibadian, dan watak. Istilah karakter berasal dari bahasa Yunani "charassein" dan "kharax" yang maknanya tools for making atau to engrave yang artinya mengukir, yang kemudian banyak digunakan kembali dalam bahasa Prancis "character", selanjutnya diadopsi dalam bahasa Inggris menjadi "character", dan akhirnya diterjemahkan dalam bahasa Indonesia sebagai karakter (Alfret Jhon dalam Rifki Afandi, 2011: 87). Lickona (2015: 13) secara sederhana mengartikan karakter sebagai kepemilikan akan hal-hal yang baik. Hal-hal baik yang dimiliki oleh individu dapat dimaknai sebagai karakter yang harus dikembangkan. Nel Noddings (2002: 3) mengartikan karakter sebagai the possession and active manifestation of those character traits called virtues. Noddings memaknai karakter sebagai sifat-sifat positif yang dimiliki seseorang dalam bentuk kebajikan-kebajikan. Ngainun Naim (2012: 60) memaknai manusia yang berkarakter adalah manusia yang dalam perilaku dan segala hal yang berkaitan dengan kativitas hidupnya sarat dengan nilai-nilai kebaikan. 


\section{Pengertian Pendidikan Karakter}

Banyak istilah yang digunakan dalam pendidikan yang berkenaan dengan watak, budi pekerti, atau etika. Berkowitz (William Damon, 2002: 44) mengatakan bahwa penggunaan istilah pendidikan moral masih banyak digunakan di berbagai negara di Asia, seperti Jepang menggunakan istilah moralogy, dan Inggris menggunakan istilah values education (William Damon, 2002: 44). Muchlas Samani dan Hariyanto (2012: 45) mendefinisikan pendidikan karakter sebagai proses pemberian tuntunan kepada peserta didik untuk menjadi manusia seutuhnya yang berkarakter dalam dimensi hati, pikir, raga, rasa, dan karsa. Nurla Isna Aunillah (201l: 18) mengartikan pendidikan karakter sebagai sebuah sistem yang menanamkan nilai-nilai karakter pada peserta didik, yang mengandung komponen pengetahuan, kesadaran individu, tekad, serta adanya kemauan dan tindakan untuk melaksanakan nilai-nilai.

Williams dan Schnaps dalam Zubaedi (2011: 15) mengartikan pendidikan karakter sebagai berbagai usaha yang dilakukan oleh personel sekolah, dan bahkan melibatkan orang tua dan masyarakat untuk membantuanak-anak dan remaja agar menjadi atau memiliki sifat peduli, berpendirian, dan bertanggung jawab. Lickona dalam Chusna Arifah (2015: 74) menyatakan bahwa "character education is the deliberate effort to develop virtues that are good for individual and good for society".

Hakikat pendidikan karakter adalah pendidikan nilai luhur yang bersumber dari budaya bangsa Indonesia sendiri dan nilai-nilai agama yang dianut dalam rangka membina peserta didik (Syaiful Sagala, 2013: 309). Nilainilai karakter dapat digali dari budaya bangsa dan nilai-nilai yang terkandung dalam agama yang dianut seseorang. Kearifan local dapat digunakan sebagai sumber nilai karakter bagi kelompok masyarakat tertentu.

Pendidikan karakter di sekolah/madrasah adalah upaya yang terencana untuk memfasilitasi peserta didik mengenal, peduli, dan menginternalisasi nilai-nilai karakter secara terintegrasi melalui proses pembelajaran, kegiatan pembinaan peserta didik, dan kegiatan manajemen sekolah/madrasah (Kemendiknas, 201l: 1-2). Lockwood dalam Arthur (Larry P. Nuci dan Darcia Narvaez, 2008: 131) mendefinisikan pendidikan karakter setiap program lembaga sekolah, dirancang dengan bekerja sama dengan lembaga-lembaga mayarakat lainnya, untuk membentuk secara langsung dan sistematis perilaku kaum muda dengan mempengaruhi secara jelas nilai-nilai nonrelativistik yang diyakini secara langsung menghasilkan perilaku tersebut. Dalam pengertian ini, pendidikan karakter tidak dapat berjalan sendiri oleh sekolah tetapi harus melibatkan berbagai lembaga dalam upaya menentukan nilai-nilai yang diyakini bersama dapat membentuk perilaku terpuji. Selain itu, masukan dari lembaga-lembaga masyarakat dapat membantu menemukan strategi dan pendekatan yang tepat dalam implementasinya. Pelibatan lembaga masyarakat dapat dipahami bahwa hasil dari pendidikan karakter akan bermuara pada masyarakat luas. Kehidupan bermasyarakat 
akan menjadi lebih baik jika setiap individu dalam masyarakat tersebut memiliki karakter yang baik.

Pendidikan karakter merupakan upaya yang terencana untuk memfasilitasi peserta didik mengenal dan menginternalisasi nilai-nilai karakter sehingga menjadi individu-individu dengan moralitas dan budi pekerti yang baik. Lickona (1997: 65) menyebutkan bahwa pendidikan karakter mengandung tiga unsur, yaitu: moral knowledge (pengetahuan tentang moral), moral feeling (sikap berkenaan dengan moralitas), dan moral behavior (perilaku bermoral). Dengan demikian, pendidikan karakter menyangkut aspek kognitif, psikomotorik, dan afektif. Pada tahap awal, individu perlu memahami tentang moralitas sebagai landasan pemahaman tentang baik dan buruk, pantas dan tidak pantas, terpuji dan tidak terpuji, dan sebagainya. Setelah memliki pemahaman tentang moral, maka tahap selanjutnya adalah individu harus memiliki perasaan berkenaan dengan moral dan akhirnya berperilaku sesuai dengan nilai moral tersebut.

\section{Sumber Nilai Karakter}

Nilai-nilai karakter yang harus ditanamkan pada peserta didik dapat berasal dari berbagai sumber, seperti agama, nilai-nilai luhur bangsa, dan budaya. Kementerian Pendidikan Nasional (2010: 9) mengidentifikasi 4 sumber utama nilai-nilai karakter, yaitu agama, Pancasila, budaya, dan tujuan pendidikan nasional. Sumber-sumber nilai karakter yang hampir sama juga dikemukakan oleh Berkowitz dalam William Damon (2002: 53-55) mengemukakan bahwa "family (especially parents) is typically considered the predominant influence on child's character formation. Additionally, school, peers, community (including the media), religion, and biology are contributors". Nilai-nilai karakter dapat digali dari budaya bangsa dan nilai-nilai yang terkandung dalam agama yang dianut seseorang.

Arthur dalam Nucci dan Narvaez (2008: 131) mengidentifikasi beberapa sumber yang dapat berpengaruh secara signifikan terhadap pembentukan karakter, seperti media massa, komunitas agama, budaya pemuda, kelompok sebaya, organisasi sukarela, dan terutama orang tua dan saudara. Bhikkhu Jayamedho dalam Sutar Soemitro dan Widodo (2015: 53 60) menyebutkan 4 faktor bembentuk karakter, yaitu: (1) kondisi dan nilainilai yang dianut keluarga, seperti adat, budaya, dan agama; (2) nilai-nilai yang dianut selama bersekolah; (3) nilai-nilai komunitas tempat individu tinggal dan bergaul, termasuk komunitas agama; dan (4) kondisi masyarakat umum, politik, dan negara.

Berkenaan dengan agama sebagai sumber nilai karakter, umat Buddha dapat menggali nlai-nilai yang termuat dalam kitab suci Tripitaka. Dalam kitab suci Tripitaka, tidak ada bagian khusus yang membahas tentang karakter. Nilai-nilai karakter dapat digali di seluruh isi dari kitab tersebut. Nilai-nilai karakter dapat ditemukan pada setiap bagian dari isi kitab Tripitaka, baik dalam Sutta, Vinaya, maupun Abhiddhama. Nilai karakter 
yang disampaikan bergantung pada situasi dan konteks pada saat ajaran terebut dibabarkan. Upasaka dan Upasika sebagai umat awam memedomani pancasila Buddhis sebagai landasan moral dalam berpikir, berbicara, dan bertindak. Pancasila Buddhis mengandung nilai-nilai karakter.

Nilai karakter ideal terangkum dalam Dhammacahkapavattana Sutta, yaitu khotbah pertama Buddha. Dalam Sutta tersebut dijabarkan secara terperinci 8 karakter yang harus dicapai seseorang, yang merupakan satu-satunya jalan yang harus ditempuh untuk mencapai tujuan akhir dari setiap makhluk, yaitu Nibbana. Puji Sulani (2014: 27) merangkum nilai karakter yang bersumber dari ajaran agama Buddha, seperti dasa punnakiriya vatu, brahma vihara, sila dalam pancasila, dan dasa paramita atau sad paramita, dimana nilainilai tersebut umumnya dijadikan sebagai pedoman umat Buddha.

\section{Tujuan Pendidikan Karakter}

Dua tujuan utama pendidikan adalah membentuk siswa yang berprestasi secara akademis dan memiliki karakter yang baik. Alasan lain yang mendorong digalakkannya kembali pendidikan karakter adalah semakin merosotnya moralitas masyarakat, terutama kaum remaja. Nurul Zuriah (2015: 10-11) mengemukakan 3 alasan mengapa pendidikan moral sagat dibangkitkan kembali, yaitu: (1) melemahnya ikatan keluarga; (2) kecenderungan negative kehidupan remaja; dan (3) kebangkitan kembali dari perlunya nilai-nilai etik, moral, dan budi pekerti. Darmiyati Zuchdi (2008: 39) memaknai tujuan pendidikan watak (karakter) untuk mengajarkan nilai-nilai tradisional tertentu, nilai-nilai yang diterima secara luas sebagai landasan perilaku yang baik dan bertanggung jawab.

Pendidikan karakter merupakan upaya untuk membentuk individu yang berkeperibadian muila. Dharma Kesuma, dkk. (2012: 9-11) mengidentifikasi 3 tujuan pendidikan karakter dalam seting sekolah, yaitu: (1) menguatkan dan mengembangkan nilai-nilai kehidupan yang dianggap penting penting dan perlu sehingga menjadi kepribadian peserta didik yang khas; (2) mengoreksi perilaku peserta didik yang tidak sesuai dengan nilainilai yang dikembangkan sekolah; dan (3) membangun koneksi yang harmoni dengan keluarga dan masyarakat dalam memerankan tanggung jawab pendidikan karakter secara bersama.

Nurla Isna Aunillah (2011: 97-106) mengelompokkan tujuan pendidikan karakter menjadi 2, yaitu menurut pemerintah dan pengamat. Tujauan pendidikan karakter menurut pemerintah adalah: (1) membentuk manusia Indonesia yang bermoral; (2) membentuk manusia Indonesia yang cerdas dan rasional; (3) membentuk manusia Indonesia yang inovatif dan bekerja keras; (4) membentuk manusia Indonesia yang optimis dan percaya diri; dan (5) membentuk manusia Indonesia yang berjiwa patriot. Tujuan pendidikan karakter menurut pengamat adalah membentuk masyarakat yang tangguh, kompetetif, berakhlak mulia, bermoral, bertoleran, bergotong-royong, berjiwa patriotik, berkembang dinamis, serta berorientasi pada ilmu pengetahuan dan 
teknologi, dilandasi iman dan takwa kepada Tuhan Yang Maha Esa serta berlandaskan pancasila.

Pendidikan karakter dapat pula dimanfaatkan dalam upaya meningkatkan prestasi akademik. Prestasi akademik yang kurang sering kali bukan disebabkan siswa yang bodoh, tetapi karena karakter yang tidak baik, seperti malas, mudah menyerah, suka meyontek, dan kenakalan. Jika karakter buruk tersebut dihilangkan dan diubah menjadi karakter yang baik, seperti rajin belajar, tidak mudah menyerah, semangat, dan termotivasi maka prestasi akademik akan meningkat. Lickona (2015: 149-150) menyebutkan 2 syarat agar pendidikan karakter mampu meningkatkan prestasi akademik, yaitu: (1) pendidikan karakter dapat meningkatkan hubungan manusia antara orang dewasa dengan siswa dan antar siswa sehingga meningkatkan kualitas lingkungan pembelajaran dan (2) upaya pendidikan karakter harus menckup program akademik yang kuat dalam mengajarkan keterampilan dan kebiasaan bekerja keras. Dari pernyataaan tersebut, pendidikan karakter jika diarahkan dan dikelola dengan baik akan mampu meningkatkan prestasi akademik sehingga tujuan akhir dari pendidikan untuk membentuk manusia yang berprestasi dan ber akhlak mulia tercapai.

Matthew Davidson, dkk. dalam Nucci dan Navarez (2008: 539-540) mengemukakan 3 tujuan dari pendidikan karaketr, yaitu: (1) mempersiapkan kaum muda menjalani kehidupan yang berkembang; (2) membantu mengurangi perilaku negative ole kaum muda yang dapat merugikan diri mereka dan masyarakat; dan (3) menawarkan upaya mengatasi akar perilaku anti-sosial atau merusak diri sendiri.

\section{Pelaksanaan Pendidikan Karakter di Sekolah}

Penanaman karakter sejak usia sekolah merupakan tujuan utama dari pendidikan karakter. Pendidikan karakter harus mengacu pada nilai-nilai tertentu sebagai nilai utama (core values) sebagai landasan dalam berpikir dan bertindak, tanpa mengabaikan nilai-nilai karakter lainnya. Nilai-nilai yang lain tersebut merupakan penjabaran maupun pendukung dari core values. Para pendidik harus mampu mendesain program pembelajaran yang mampu mengintegrasikan pendidikan karakter dalam setiap aktivitas peserta didik di sekolah. Ki Supriyoko (2015: 185) mengajukan keteladanan sebagai sebuah pendekatan pendidikan karakter yang paling efektif dan produktif, yaitu dengan cara meneladani perilaku baik orang lain.

Lickona (1997: 65) menyatakan bahwa comprehensive character education asserts that effective character education must encompass the total moral life of the classroom and school. Selain itu, untuk menjamin keberhasilan pelaksanaan pendidikan karakter di sekolah diperlukan peran serta orangtua dan masyarakat. Schaeffer dalam Yener Ozen (2011: 67) menyatakan bahwa proses pendidikan karakter dan proses pendidikan secara umum akan bermakna jika melibatkan orangtua dan masyarakat. 
Bill Puka dalam Arthur (dalam Nucci dan Navarez, 2014: 135) mengidentifikasi 6 metode pengajaran yang dapat digunakan dalam program pendidikan karakter, yaitu: (1) arahan dalam nilai-nilai dan kebajikan dasar; (2) aturan perilaku yang ditetapkan dan dilaksanakan; (3) bercerita dengan pelajaran moral; (4) memperagakan sifat dan nilai-nilai yang diinginkan; (5) menceritakan para teladan moral dalam sejarah, literature, agama, dan memuji sifat-sifatnya; dan (6) menyediakan di sekolah dan masyarakat peluang yang terjangkau (proyek pengabdian) sebagai arana siswa memprktekkan sifat-sifat baik dan mengejar sifat-sifat baik tersebut.

SUNY Cortland dalam Lickona (1997: 65-79) telah menyusun model pendidikan karakter yang komprehensif, terdiri dari 12 komponen yang saling berkaitan dengan 9 komponen berkenaan dengan aktivitas kelas dan 3 lainnya berkaitan dengan aktivitas di luar kelas. Duabelas komponen model pendidikan karakter komprehensif tersebut, yaitu: (1) the teacher as caregiver, moral model, and moral mentor; (2) creating a caring classroom community; (3) moral discipline; (4) creating a democratic classroom environmental; (5) teaching values through the curriculum; (6) cooperative learning; (7) the conscience of craft; (8) ethical reflection; (9) teaching conflict resolution; (10) steer-clear-of-controversy approach; (11) remain-impartial approach; dan (12) take-a-stand approach.

Howard, dkk. dalam Sue Winton (2008: 45) mengidentifikasi 3 pendekatan utama dalam pelaksanaan pendidikan karakter, yaitu the cognitivedevelopmental approaches, the caring approaches, dan the traditional character education approaches. Lebih lanjut, Sue Winton (2008: 48-55) menjelaskan pola-pola pelaksanaan pendidikan karakter berdasarkan pendekatan pendidikan karakter secara tradisional (the traditional character education approaches), yaitu: universal values, direct teaching, role modeling, curriculum integration, developing character through action, decision makingdeversity, dan conflict.

\section{Metode Penelitian}

Jenis penelitian ini adalah penelitian deskriptif kualitatif. Penelitian ini bertujuan untuk menjelaskan pola pelaksanaan pendidikan karakter di SD Insan Teratai dimana proses penelitiannya menggunakan pendekatan kualitatif. Penelitian dilaksanakan di SD Insan Teratai selama 4 bulan. Fokus dalam penelitian ini adalah pola pelaksanaan pendidikan karakter di SD Insan Teratai Tangerang dengan objek penelitiannya adalah aktivitas kepala sekolah, guru, peserta didik, dan orangtua/wali peserta didik baik di dalam maupun di luar kelas. Teknik pengumpulan data yang digunakan dalam penelitian ini adalah observasi, dokumentasi, dan wawancara. Untuk menguji keabsahan data digunakan uji kredibilitas (validitas internal), tranferabilitas (validitas eksternal), dependabilitas (reliabilitas), dan konfirmabilitas (objektivitas). Sedangkan teknik analisis data menggunakan interactive model Miles dan Huberman, yang meliputi data collection, data reduction, data display, dan conclusion. 


\section{Pembahasan}

SD Insan Teratai merupakan sekolah umum yang berada di bawah naungan Yayasan Insan Teratai Sejati yang merupakan sebuah yayasan bercirikan keagamaan Buddha. Keperihatinan terhadap mutu pendidikan di Indonesia yang tidak kunjung membaik dan menurunnya moral masyarakat, terutama pada anak-anak usia sekolah telah membangkitkan semangat para pendiri untuk mendirikan sekolah yang meletakkan pendidikan karakter sebagai fokus utama tanpa mengabaikan bidang akademis. Selain itu, Yayasan Insan Teratai Sejati berkeinginan untuk memberikan kesempatan kepada anak-anak dari keluarga kurang mampu di wilayah Desa Gelam Jaya dan sekitarnya untuk memperoleh pendidikan yang layak dan murah. Untuk memperkuat karakter siswa, maka yayasan mengambil kebijakan untuk memasukkan muatan Penanaman Nilai-Nilai Kemanusiaan (PNK) ke dalam kurikulum dan secara jelas tertuang dalam visi "Unggul dalam Karakter, Cerdas dan Berpretasi dalam Belajar dengan Penidikan Nilai-Nilai Kemanusiaan" dan misi: (1) menyiapkan generasi yang unggul berdasarkan nilai-nilai kemanusiaan dan (2) menjadikan nilai-nilai kemanusiaan sebagai filosofi dasar pendidikan yang dijalankan sekolah. Visi dan misi tersebut dijabarkan lebih jelas pada kurikulum dan terinci dalam sebaran mata pelajaran.

Meskipun berada di bawah naungan yayasan pendidikan bercirikan keagamaan Buddha, sekolah yang dikelola bersifat umum sehingga tidak membatasi siswa, guru, maupun pegawai yang ingin berkontribusi terhadap kemajuan sekolah. Setiap siswa mendapat pembelajaran pendidikan agama sesuai dengan agama dan keperayaan masing-masing, yang diperkuat melalui kegiatan ekstrakurikuler (Baca Tulis Alquran bagi yang muslim) dan bimbingan rohani saat libur panjang sekolah.

\section{Nilai Dasar dalam Pola Pendidikan Karakter di SD Insan Teratai}

SD Insan Teratai merupakan salah satu sekolah yang sangat serius terhadap perkembangan moralitas siswanya. Bentuk upaya yang dilakukan oleh sekolah adalah memasukkan nilai-nilai karakter ke dalam kurikulum dan mengimplementasikkannya ke dalam setiap aktivitas yang ada di sekolah. Nilai-nilaik kakarker yang hendak ditanamkan pada diri siswa dikemas dalam pola Penenaman Nilai Kemanusiaan (PNK). Pola PNK memiliki 5 nilai dasar (core values), yaitu: kebenaran (truth), kedamaian (peace), kasih sayang (love), kebajikan (righteousness/right conduct), dan tanpa kekerasan (non violence). Melalui 5 nilai dasar ini diharapkan akan tercipta manusiamanusia yang seutuhnya (human exellence). Manusia seutuhnya atau human exellence dapat dimaknai sebagai manusia yang memiliki kecerdasan akademik dan karakter mulia. PNK sangat cocok sebagai pola pelaksanaan pendidikan karater yang dalam upaya menanamkan, membangun, dan menumbuhkan toleransi dan saling menghormati di antara siswa yang memiliki berbagai perbedaan, seperti agama, suku, budaya, dan status sosial. 
Untuk memperkuat implementasi 5 nilai dasar di atas, pada tangga menuju ke lantai 2 tertulis nilai-nilai karakter sebanyak 22 butir yang disebut sebagai 22 noble of living. Duapuluh dua noble of living tersebut, yaitu: (1) good health (kesehatan), dimana seorang individu yang berkarakter haruslah memiliki kesehatan jasmani; (2) morality (sikap baik), diligence (rajin), respect (menghargai), harmony (harminis), service (melayani), cleanliness (kebersihan), honest (jujur), truth (kebenaran), forgiveness (memaafkan), peaceful (damai), politeness (kesopanan), amiable (ramah), discipline (disiplin), compassion (belas kasih), gratitude (beryukur), moral shame (malu berbuat jahat), moral dread (takut akibat perbuatan jahat), attentive (penuh perhatian), loving-kindness (cinta kasih), dan sincere (tulus). Keduapuluh dua nilai-nilai karakter tersebut diambil dan disarikan dari syair-syair Dhammapada oleh seorang bhikkhu yang berkesempatan mengunjungi sekolah Insan Teratai. Nilai-nilai yang bersumber dari ajaran agama Buddha bersifat universal sehingga dapat masuk dan diterima oleh seluruh lapisan orangtua dan siswa. Jika ditelusuri lebih lanjut, kelima nilai dasar (core values) di atas juga merupakan nilai-nilai karakter yang berasal dari ajaran agama Buddha. Meskipun demikian tetap ada nilai-nilai tertentu yang khas atau unik dan tidak terdapat pada ajaran agama lain yang dilaksanakan di SD Insan Teratai. Nilai-nilai khas yang bersumber dari ajaran agama Buddha tersebut, antara lain:

a. Duduk Hening (Silent Sitting)

Silent sitting merupakan aktivitas sehari-hari yang dilakukan sebelum mengawali kegiatan pembelajaran di kelas. Silent sitting merupakan kegiatan meditasi dengan objek cahaya. Silent sitting diikuti seluruh siswa dan guru dengan dibimbing oleh rekaman yang menuntun proses meditasi dari awal sampai akhir. Pelaksanaan silent siting berlangsung selama 15 menit. Sesuai dengan namanya, semua orang duduk bersila dengan posisi badan tegak. Selain itu, pada kegiatan yang melibatkan orangtua selalu diawali dengan sesi silent sitting untuk mengenalkan meditasi pada khalayak umum.

b. Vegetarian

SD Insan Teratai mengeluarkan kebijakan kepada seluruh warga sekolah tidak diperkenankan untuk membawa makanan dan makan makanan yang mengandung unsur kekerasan di lingkungan sekolah. Untuk menjaga efektivitas dari program ini, sekolah menyediakan makan siang untuk seluruh siswa, guru, dan karyawan. Makan siang yang disediakan berupa nasi, sayurmayur, dan lauk seperti telur, tahu, dan tempe. Tugas siswa adalah membawa kotak makan dan botol air minum. Sayur yang dimasak sebagian merupakan hasil berkebun, seperti terong, kacang panjang, dan caisim.

c. Konsep Mengalahkan Diri Sendiri

SD Insan Teratai mengenalkan konsep lain berkenaan dengan persaingan yang mungkin tidak pernah diterapkan di sekolah lain. Setiap siswa diajarkan untuk bersaing dengan diri sendiri. Setiap siswa diajarkan untuk mengalahkan diri sendiri, bukan bersaing dengan siswa lain. 
Mengalahkan diri sendiri mengandung makna bahwa setiap siswa harus lebih baik, maju, dan semakin berkembang. Setiap siswa harus menjadi lebih rajin, bersemangat, percaya diri, dan maju dari sebelumnya.

Masih banyak nilai-nilai karakter yang harus dimiliki siswa, antara lain: harus tenang saat makan, melayani dan mudah dilayani, harmonis dalam perbedaan, leadership, menghormati, disiplin, rapi, cinta tanah air, konsentrasi, tidak jahat, belajar tertib/antri, religius, sabar, menghargai makanan, sopan, bertakwa, percaya diri, kerja sama, adil/tidak membeda-bedakan, menyayangi, menghargai, teguh, rukun, kerja keras, pemaaf, kreatif dan inovatif, sederhana, bersyukur, tanggung jawab, dan sopan. Dengan alasan tersebut, sekolah banyak memasang tulisan-tulisan berkaitan dengan karakter tertentu maupun gambar, seperti 10 budaya malu guru, 10 budaya malu siswa, pohon ilmu lengkap dengan karakter-karakternya, kata-kata bijak, saling meghargai antar sesama agama, dan 7 karakter guru PNK.

\section{Bentuk Kegiatan dalam Pelaksanaan Pendidikan Karakter di Sekolah Insan Teratai}

Dalam bentuk kebijakan, SD Insan Teratai menyusun kurikulum berdasarkan kebutuhan dan disesuaikan dengan visi dan misi sekolah. Implementasi pendidikan karakter di SD Insan Teratai dikemas dalam pola Penanaman Nilai-Nilai kemanusiaan (PNK). PNK dimasukkan dalam KTSP sehingga kurikulum yang digunakan merupakan kurikulum yang diperkaya. Kurikulum yang diperkaya ini menjadi landasan penyelenggaraan pendidikan di sekolah. Setiap aktivitas akademis dan non akademis selalu mengacu pada kurikulum tersebut, sehingga nilai-nilai PNK selalu turut serta.

PNK merupakan ciri atau pembeda dengan sekolah lain pada umumnya. PNK lebih menitikberatkan pada pembentukan budi pekerti atau moralitas yang baik, yang pada akhiran juga membentuk siswa menjadi cerdas secara akadmik. Penambahan muatan PNK merupakan upaya menanamkan, menumbuhkan, dan memperkuat karakter tanpa mengabaikan sisi kecerdasan siswa. Muatan PNK diadopsi dari Institut Sathya Sai Education Indonesia (ISSEI) dengan konsep Educare. Educare mengusung misi kasihi semua, layani semua, dan pentingnya semua nilai kemanusiaan. Educare menjadi sebuah strategi dalam memadukan kebijaksanaan (wisdom) zaman dulu dengan teknologi modern. Menurut educare, hasil akhir dari pendidikan adalah karakter.

Kegiatan pembelajaran di kelas selalu didasari pada PNK. Setiap mata pelajaran diatur dan ditambah dengan muatan PNK. Setiap guru harus mengajar dan mendidik siswa dengan penuh perhatian dan kesabaran, tanpa membeda-bedakan. Untuk membangun sikap spiritual, siswa mengikuti pembelajaran pendidikan agama sesuai dengan agama masing-masing. Untuk memperkuat sikap spiritual tersebut, siswa juga diberikan bimbingan rohani pada saat libur panjang. Bahkan, untuk siswa muslim disediakan ekstrakurikuler baca tulis Alquran dan marawis. Dari kegiatan tersebut, 
sekolah sangat memperhatikan perkembangan dan pemahaman spiritual siswanya. Beberapa contoh penerapan PNK dalam mata pelajaran adalah seperti pada soal Matematika disisipkan nilai berbagi, kasih sayang. Dalam mata pelajaran SBK, sebelum siswa mewarnai sebuah gambar, maka harus memilih dulu gambar yang sesuai dengan nilai-nilai tertentu. Pemilihan lagulagu yang dinyanyikan juga menjadi perhatian yang sangat serius. Lagu-lagu yang dinyanyikan umumnya adalah lagu yang bertema PNK. Meskipun demikian, lagu lain juga dapat dinyanyikan asalkan tidak mengandung unsur SARA dan kekerasan. Selain itu, pemberian hukuman untuk siswa yang melakukan pelanggaran atau bertengkar diberikan melalui cara tanpa kekerasan. Siswa yang dihukum diminta untuk berdiri di kotak merah untuk pelanggaran ringan dan kotak hitam untuk pelanggaran berat, tetapi siswa masih mendapat kesempatan untuk mengikuti pembelajaran. Hukuman juga diberikan kepada siswa dengan duduk di bangku tinggi. Siswa hanya diperbolehkan membawa buku tulis dan pensil. Ketika siswa salah mencatat maka harus turun untuk menghapusnya dan kembali lagi ke bangku, sehingga harus berhati-hati dalam mencatat.

Pelaksanaan pendidikan karakter melalui pola PNK di luar kelas dilaksanakan sejak siswa mulai memasuki halaman sekolah. Guru yang mertugas piket menyambut siswa di pintu batas orangtua mengantar anaknya dengan beranjali. Setiap siswa mengucapkan salam "Good morning, Teacher" atau Selamat pagi, Teacher" sambil beranjali. Kegiatan di luar kelas yang memuat PNK dan mendukung peningkatan kemampuan akademis siswa dan dilaksanakan setiap hari, antara lain:

a. Duduk Hening (Silent Sitting)

Duduk hening merupakan aktivitas awal yang dilakukan untuk memulai serangkaian kegiatan di sekolah. Kegiatan duduk hening diikuti oleh seluruh guru dan siswa. Peserta silent sitting duduk bersila dengan posisi badan tegak. Silent sitting menggunakan objek cahaya sebagai pusat perhatian. Pada saat silent siting berlangsung, para peserta mengikuti instruksi dari rekaman yang berfungsi untuk menuntun jalannya meditasi. Silent sitting memakan waktu kurang lebih 15 menit. Tujuan utama dari silent sitting adalah menyiapkan siswa secara psikologis sehingga siap untuk mengikuti pembelajaran di kelas. Salah satu hasil positif yang diperoleh dari kegiatan silent sitting yang dilakukan secara rutin sebelum memulai kegiatan adalah siswa mudah diajari karena memiliki konsentrasi yang baik. Siswa dilatih untuk mengendalikan pikiran. Duduk hening juga berfungsi untuk membangun harmoni dan keselarasan dengan alam karena setiap tarikan dan hembusan napas berhubungan dengan alam. Selain itu, duduk hening dapat membangkitkan suasana damai dan tenang pada seluruh warga sekolah.

b. Doa Bersama

Doa bersama merupakan kegiatan yang dilakukan setelah sesi silent sitting. Setiap agama diwakili oleh satu orang siswa untuk membacakan doa 
secara bergiliran. Manfaat yang dapat dipetik dari kegiatan doa bersama adalah menumbuhkan toleransi dan saling menghormati antar pemeluk agama yang berbeda-beda. Seluruh siswa dilatih untuk menghormati umat lain yang sedang berdoa. Siswa diajarkan pula untuk tidak fanatik dengan agama sendiri dan alergi terhadap agama lain. Pada saat pelaksanaan, dijumpai siswa yang berusaha mengingatkan siswa lain untuk berdoa dengan sikap tangan yang sesuai (beranjali, menengadah ke atas).

c. Story Telling

Story telling merupakan aktivitas yang dilaksanakan setelah doa bersama yang diikuti oleh seluruh siswa dan guru. Story telling merupakan penyampaian pesan moral, motivasi, dan inspirasi melalui suatu cerita. Story telling merupakan salah satu kegiatan penanaman nilai-nilai karakter tertentu melalui cerita. Pada story telling Setiap guru mendapat giliran untuk menyampaikan cerita yang mengandung pesan moral atau karakter positif. Bahkan, kadang-kadang beberapa siswa dilatih untuk memerankan sebuah cerita tertentu dalam story telling. Cerita yang disampaikan dapat berupa kisah binatang, orang sukses, tokoh, pahlawan, dan sebagainya sehingga mengandung unsur moralitas, karakter, motivasi, dan inspirasi. Tujuan dari story telling adalah memberikan kisah keteladanan, motivasi, dan inspirasi sehingga siswa meresapi nilai-nilai tersebut.

d. Makan Bersama

Makan bersama merupakan aktivitas yang dilakukan pada waktu istirahat. Makanan disediakan oleh sekolah. Makanan disiapkan dan dimasak oleh orangtua siswa yang bersedia membantu dan diberi gaji setiap bulan. Makanan yang disediakan oleh sekolah adalah makanan vegetarian yang tidak mengandung unsur kehidupan dan kekerasan. Seluruh warga sekolah tidak diperkenankan membawa makanan dari rumah. Siswa hanya membawa kotak makan dan botol air minum. Setiap siswa mendapat giliran untuk membagikan makanan kepada siswa lain. Siswa yang lain mengantri dengan rapi untuk mendapat giliran dengan menyodorkan kotak makan yang telah dipersiapkan dari rumah. Siswa yang ingin menambah makanan juga diperkenankan.

Di dinding ruang makan dipasang gambar yang sangat besar yang menceritakan proses pengolahan bibit padi sampai menjadi nasi yang siap untuk dinikmati. Setiap siswa dapat melihat gambar tersebut pada saat makan. Dari gambar tersebut, diharapkan siswa dapat menghargai setiap butir nasi dan makanan yang dimakan dengan cara meminta makanan dan sayuran sesuai dengan takaran masing-masing sehingga tidak ada yang tersisa.

Manfaat yang diperoleh dari makan bersama, antara lain: (l) siswa dibiasakan berdoa sebelum makan; (2) belajar melayani orang lain ketika membagikan makanan; (3) belajar untuk mudah dilayani; (4) siswa dibiasakan untuk mengambil makanan sesuai dengan takarannya sendiri sehingga tidak tersisa; (5) membiasakan budaya antri; (6) siswa lebih 
menghargai makanan; dan (7) siswa dibiasakan untuk menggosok gigi setelah makan.

Selain kegiatan yang dilaksanakan setiap hari, upaya pendidikan karakter melalui PNK dilaksanakan secara periodik. Kegiatan tersebut, antara lain:

a. Peringatan Hari Nasional

Peringatan hari nasional selalu diperingati di SD Insan Teratai. Peringatan hari nasional, seperti Hari Ulang Tahun kemerdekaan, Hari Ibu, dan Hari Kartini diperingati untuk mengingatkan kembali jasa-jasa para pahlawan. Mengingat dan meneladani sifat-sifat pahlawan dan memupuk rasa cinta terhadap tanah air. Dalam setiap peringatan, siswa selalu melakukan aktivitas, seperti membuat bendera merah putih dari kardus, mewarnai gelas air mineral dengan warna merah putih untuk hiasan. Pada peringatan Hari Ibu, setiap siswa memberikan bunga dan bersujud pada orangtua.

b. Peringatan Hari Raya Keagamaan

Peringatan hari raya keagamaan dirayakan oleh seluruh siswa meskipun bukan hari raya agama yang dianutnya. Kegiatan untuk memperingati hari raya keagamaan, antara lain: mewarnai telur Paskah, membuat kartu ucapan selamat hari Waisak, Idul Fitri, dan Natal. Pada saat hari raya Imlek, seluruh siswa mengenakan pakaian berwarna merah-merah dan membuat lampion dari angpau. Tujuan dari pelibatan seluruh siswa dalam merayakan hari raya keagamaan adalah supaya siswa saling mengetahui dan mengenal ajaran berbagai agama (hanya sebagai pengetahuan bukan untuk mempengaruhi) sehingga tercipta saling menghargai dan menghormati, tidak salah menilai agama lain, dan bahkan saling mencurigai. c. Upacara Bendera

Upacara bendera dilaksanakan setiap hari Senin dan diikuti oleh seluruh siswa, guru, dan karyawan. Seluruh kelas mendapat giliran menjadi petugas upacara. Makna dari upacara bendera adalah memupuk rasa cinta tanah air, keteladanan, dan menghargai jasa para pahlawan. Selain itu, upacara bendera juga bermanfaat untuk mendisiplinkan dan membentuk rasa percaya diri.

d. Ekstrakurikuler

Ekstrakurikler diadakan untuk megakomodasi bakat, minat, dan potensi siswa. Kegiatan ekstrakurikuler yang diadakan di SD Insan Teratai, antara lain: Marawis dan Baca Tulis Alquran (BTQ) untuk yang beragama Islam, Pramuka, Futsal, English Club, Mandarin Club, Art Club (melukis), Math Club, Sains Club, Sepak Takraw, Angklung, Tari tradisional, dan drum band. Tujuan dari disediakannya berbagai kegiatan ekstrakurikuler adalah untuk memfasilitasi potensi, bakat, dan minat dari seluruh siswa. Siswa dapat memilih kegiatan ekstrakurikuler sesuai dengan minat dan bakatnya. 


\section{e. Karya Wisata (Field Trip)}

Field trip merupakan kegiatan yang dilaksanakan dengan mengunjungi suatu tempat sehingga siswa dapat mempelajari dan memperoleh nilai/karakter dari tempat tersebut. Nilai atau karakter yang menjadi sasaran field trip bergantung dari tempat yang dikunjungi. Tempat-tempat yang pernah dikunjungi untuk field trip, antara lain: planetarium, peternakan, kebun sayur, pabrik tahu, sawah, dan kebun binatang. Siswa diberi tugas untuk mengamati segala sesuatu yang dijumpai dan melakukan wawancara kepada petugas. Manfaat yang diperoleh dari field trip, antara lain: (1) meningkatkan kepercayaan diri siswa; (2) memahami suatu proses, seperti pembuatan tempe, menanam sayur, dan beternak; (3) menambah wawasan siswa; dan (4) bersyukur.

f. Kelas Integrasi

Kelas integrasi merupakan kelas tambahan yang melibatkan seluruh siswa dan dilaksanakan secara moving class yang dilaksanakan setahun 3 kali. Seluruh siswa dibagi ke dalam kelompok-kelompok kecil yang terdiri dari seluruh kelas yang ada. Kadang-kadang kelas integrasi juga melibatkan siswa dari unit Taman Kanak-Kanak. Siswa dari kelas besar akan ditunjuk menjadi ketua kelompok yang berfungsi untuk mengatur anggota kelompoknya, terutama yang berasal dari kelas kecil. Materi yang diberikan disesuaikan dengan tema kelas integrasi dan terbagi dalam sub-sub kecil. Tema yang pernah diambil dalam kelas integrasi, antara lain: kelapa, warna, dan profesi. Isi dan nilai karakter yang ditanamkan bergantung dari tema kelas integrasi, yang biasanya berkembang sesuai dengan yang digali siswa.

g. Kebun Sayur

Beberapa nilai yang dapat diperoleh dari kebu sayur adalah siswa dilatih untuk menanam, memelihara, dan memanennya. Siswa dapat mengetahui jenis-jenis sayuran secara langsung, Siswa juga belajar untuk bertanggung jawab dalam memelihara tanaman. Selain itu, siswa dapat menghargai makanan yang dimakan karena untuk memperolehnya sangat sulit dan membutuhkan waktu yang lama.

h. Bimbingan Rohani

Untuk meningkatkan keyakinan dan ketakwaan siswa terhadap Tuhan Yang Maha Esa, sekolah menyelenggarakan bimbingan rohani untuk seluruh siswanya pada saat libur panjang kenaikan kelas. Kegiatan dilaksanakan selama beberapa hari. Siswa yang beragama beragama Buddha mengikuti Dhamma Class. Siswa yang beragama Islam mengikuti Sanlat (Pesantren Kilat). Siswa yang beragama Kristen mengikuti Retret. Siswa yang beragama Katholik mengikuti Rekoleksi. Kegiatan bimbingan rohani ini bersifat wajib untuk seluruh siswa.

Peran serta dari orangtua siswa sangat diperlukan untuk membantu menigkatkan potensi dan kemampuan siswa, baik di bidang akademik maupun non-akademik. SD Insan Teratai melibatkan orangtua siswa dalam berbagai kegiatan, antara lain: 


\section{a. Parenting}

Parenting merupakan salah satu kegiatan yang dilaksanakan di SD Insan Teratai dalam upaya membangun komunikasi yang baik antara pihak sekolah dengan orangtua siswa. Selain itu, parenting juga digunakan sebagai sarana untuk menyamakan persepsi, pandangan, dan langkah-langkah yang harus ditempuh untuk mengoptimalkan tumbuh kembang siswa. Program parenting yang telah dilaksanakan berupa penyuluhan berkenaan dengan pelaksanaan pendidikan yang berbasis PNK oleh narasumber yang berasal dari Institut Sathya Sai Education Indonesia dan Sekolah Insan Teladan Parung Bogor. Selain itu ada pula parenting tentang penyuluhan kesehatan anak dan membuat masakan sehat.

Beberapa tujuan diadakan program parenting, antara lain: (1) menyamakan pola pendidikan yang ada di sekolah dan di rumah; (2) menciptakan suasana harmonis antara orangtua siswa dengan pihak sekolah; (3) meningkatkan kerja sama antara orangtua siswa dan guru dalam mendidik siswa; (4) orangtua siswa mengetahui program-program pendidikan yang dilaksanakan di sekolah; dan (5) orangtua memperoleh informasi dan pengetahuan dalam mendidik anak-anak di rumah.

b. Daur ulang

Daur ulang merupakan salah satu program yang melibatkan orangtua siswa. Di rumah orangtua bersama anaknya memilah dan mengumpulkan sampah-sampah plastik, seperti kardus, kertas, gelas dan botol air mineral untuk dibawa dan dikumpulkan di sekolah. Nilai edukasi yang hendak ditanamkan pada pada siswa di rumah adalah orangtua mendidik anaknya tentang kebersihan dan peduli terhadap lingkungan. Orangtua dapat memberi contoh kepada anaknya untuk membuang sampah pada tempatnya dan mengumpulkan sampah yang masih dapat dimanfaatkan. Pengaruh nyata dari program daur ulang adalah seorang siswa berinisiatif mengumpulkan sampah plastik dan steorofom yang mengapung di pantai ketika mengadakan liburan bersama.

c. Piket bersama

Setiap orangtua yang anaknya bersekolah di SD Insan Teratai mendapat giliran untuk melaksanakan piket satu kali per minggu Hari giliran piket disesuaikan dengan waktu yang dimiliki orangtua sehingga tidak mengganggu aktivitas dan kesibukannya. Pemberian tugas kepada orangtua untuk membantu membersihkan ruangan dan lingkungan sekolah merupakan salah satu bentuk tanggung jawab orangtua terhadap sekolah. Kegiatan kerja bakti yang melibatkan orangtua juga diadakan setiap masuk sekolah awal semester. Biasanya, saat sekolah libur panjang kegiatan piket bersama diliburkan, sehingga banyak debu dan kotoran yang harus dibersihkan sebelum digunakan untuk aktivitas sekolah. Orangtua saling bahu-membahu membersihkan lingkungan sekolah, meskipun tidak semua orangtua hadir. 


\section{d. Membantu masak di dapur}

Ada beberapa orangtua siswa yang mendedikasikan tenaganya untuk membantu menyiapkan makanan. Orangtua yang membantu memasak di dapur diberikan honor/gaji bulanan sebagai bentuk kompensasi. Selain membantu memasak di dapur, ada pula orangtua siswa yang diberi tanggung jawab sebagai koordinator piket kebersihan. Koordinator piket kebersihan bertanggung jawab terhadap pelaksanaan piket dan kebersihan lingkungan sekolah.

\section{Hambatan dan Tantangan}

Untuk mensukseskan program pendidikan karakter melalui PNK tidak selalu mulus. Hambatan yang dihadapi sekolah sampai saat ini, antara lain: (1) pemahaman guru tentang PNK belum sama; (2) setiap tahun ada guru yang masuk sehingga herus memberikan pemahaman tentang PNK dari awal; (3) belum semua guru mempraktikkan PNK; (4) pemahaman orangtua tentang PNK masih kurang; (5) dukungan orangtua siswa terhadap program PNK ketika di rumah belum maksimal; (6) beberapa guru masih kesulitan menghubungkan materi pembelajaran dengan PNK; (7) latar belakang siswa yang berbeda-beda; (8) pola pendidikan di keluarga yang berbeda-beda; (9) petunjuk pelaksanaan PNK belum jelas.

Tantangan yang dihadapi dalam mengembangkan sekolah berbasis pendidikan karakter, antara lain: (1) pemahaman masyarakat tentang pendidikan karakter masih kurang; (2) PNK merupakan program yang selalu berkembang dan dinamis; (3) optimalisasi peran orangtua dalam mendukung program PNK; (4) aktivitas siswa di sekolah cukup panjang untuk ukuran SD; (4) sosialisasi program PNK kepada masyarakat, terutama orangtua siswa; dan (5) proses yang membutuhkan waktu lama sehingga hasilnya tidak langsung terlihat.

\section{Penutup}

Pola pelaksanaan pendidikan karakter di SD Insan Teratai dikemas melalui Penanaman Nilai Kemanusiaan (PNK) yang memiliki 5 nilai inti/dasar (core values), yaitu: kebenaran (truth), kedamaian (peace), kasih sayang (love), kebajikan (right conduct), dan tanpa kekerasan (non violence). Pelaksanaan pendidikan karakter di SD Insan Teratai dibagi menjadi 2 kegiatan, yaitu (a) di dalam kelas yang terintegrasi dalam seluruh mata pelajaran dan (b) di luar kelas yang meliputi setiap aktivitas, baik rutin maupun yang dilaksanakan secara periodik, antara lain: duduk hening (silent sitting), doa bersama, story telling, makan bersama, peringatan hari nasional, peringatan hari raya keagamaan, upacara bendera, ekstrakurikuler (Marawis dan Baca Tulis Alquran untuk siswa yang beragama Islam, Pramuka, Futsal, English Club, Sains Club, Math Club, Mandarin Club, Art Club, Sepak Takraw, Angklung, Tari Tradisional, dan Drum Band), karya wisata (field trip), kelas integrasi, kebun sayur, dan bimbingan rohani. Peran orangtua dalam 
pelaksanaan pendidikan karakter di Sekolah Dasar Insan Teratai, antara lain: aktif mengikuti parenting, piket kebersihan, daur ulang, dan beberapa membantu memesak di dapur.

Hambatan yang dihadapi sekolah sampai saat ini, antara lain: pemahaman guru tentang PNK belum sama, setiap tahun ada guru yang masuk sehingga herus memberikan pemahaman tentang PNK dari awal, belum semua guru mempraktikkan PNK, pemahaman orangtua tentang PNK masih kurang, dukungan orangtua siswa terhadap program PNK ketika di rumah belum maksimal, beberapa guru masih kesulitan menghubungkan materi pembelajaran dengan PNK, latar belakang siswa yang berbeda-beda, pola pendidikan di keluarga yang berbeda-beda, dan petunjuk pelaksanaan PNK belum jelas.

Tantangan yang dihadapi sekolah, antara lain: pemahaman masyarakat tentang pendidikan karakter masih kurang, PNK merupakan program yang selalu berkembang dan dinamis, optimalisasi peran orangtua dalam mendukung program PNK, aktivitas siswa di sekolah cukup panjang untuk ukuran SD, sosialisasi program PNK kepada masyarakat, terutama orangtua siswa, dan proses yang membutuhkan waktu lama sehingga hasilnya tidak langsung terlihat.

Saran-saran yang dapat diberikan dari penelitian ini, antara lain: perlu dijabarkan nilai-nilai inti (core value) sehingga lebih mudah dan konkret dalam implementasinya. Perlu perencanaan yang matang dan evaluasi secara periodik untuk menjamin kualitas pelaksanaan setiap kegiatan.Orangtua harus dilibatkan secara intensif dalam pelaksanaan pendidikan karakter. Perlu diadakan pembinaan secara intensif dan rutin untuk guru, karyawan, dan orangtua sebagai upaya penyamaan pandangan dan tindakan dalam pelaksanaan pendidikan karakter. Mengembangkan pola, strategi, dan metode untuk implemantasi pendidikan karakter.

\section{Daftar Pustaka}

Afandi, Rifki. 2011. Integrasi Pendidikan Karakter dalam Pembelajaran IPS di Sekolah Dasar. Jurnal Pedagogia. Vol. 1 (1), p. 85-98.

Arifah, Chusna. 2015. Personality Development through Character Education In Darussalam Islamic Boarding School, Ciamis, West Java, Indonesia. International Journal of Educational Studies. Vol. 12 (3), p. 69-90.

Aunillah, Nurla Isna. 20ll. Panduan Menerapkan Pendidikan Karakter di Sekolah. Yogyakarta: Laksana.

Damon, William. 2002. Bringing in A New Era in Character Education. California: Hoover Institution Press.

Ihsan, Fuad. 2010. Dasar-Dasar Kependidikan. Jakarta: Rineka Cipta.

Kementerian Pendidikan Nasional. 2010. Bahan Pelatihan Penguatan Metodologi Pembelajaran berdasarkan Nilai-Nilai Budaya untuk Membentuk Daya Saing dan 
Karakter Bangsa. Jakarta: Badan Penelitian dan Pusat pengembangan Kurikulum Kementerian Pendidikan Nasional.

Kementerian Pendidikan Nasional. 2011. Pedoman Pelaksanaan pendidikan Karakter berdasarkan Pengalaman di satuan Pendidikan Rintisan. Jakarta.

Kesuma, Dharma, dkk. 2012. Pendidikan Karakter: Kajian Teori dan Praktik di Sekolah. Bandung: Remaja Rosdakarya.

Lickona, Thomas. 1997. The Teacher's Role in Character Education. Journal of Education. Vol. 197 (2), p. 63-80.

Lickona, Thomas. 2015. Character Matters. Jakarta: Bumi Aksara.

Naim, Ngainun. 2012. Character Building: Optimalisasi Peran pendidikan dalam Pengembangan Ilmu dan Pembentukan Karakter Bangsa. Yogyakarta: ArruzzMedia.

Noddings, Nel. 2002. Educating Moral People: A Caring Alternative to Character Education. New York: Teachers College Press.

Nucci, Larry P. dan Darcia Narvaez. 2014. Handbook Pendidikan Moral dan Karakter. Bandung: Nusa Media.

Ozen, Yener. 2011. A New Proposal for Character Education. TSA/Yil: 15 S: 3, p. 61-70.

Sagala, Syaiful. 2013. Etika dan Moralitas pendidikan. Jakarta: Kencana.

Samani, Muchlas dan Hariyanto. 2012. Konsep dan Model Pendidikan Karakter. Bandung: Remaja Rosdakarya.

Soemitro, Sutar dan Widodo. 2015. Pendidikan Karakter Berbasis Nilai-Nilai Buddhis. Jakarta: BKPBI.

Sulani, Puji. 2014. Implementasi Pendidikan Karakter di Sekolah Minggu Buddha. Jurnal Vijjacariya. Vol l (1), p. 21-35.

Supriyoko, Ki. 2015. Pendidikan Karakter Bangsa sebagai Strategi Kebudayaan. Bunga Rampai Seminar Nasional Kebudayaan 2014: Revolusi Mental Sebagai Strategi Kebudayaan. Kemendikbud.

Winton, Sue. 2008. Character Education: Implications for Critical Democracy. International Critical Childhood Policy Studies. Vol. 1 (1), p. $42-$ 63.

Zubaedi. 2011. Desain Pendidikan Karakter: Konsepsi dan Aplikasinya dalam Lembaga pendidikan. Jakarta: Kencana.

Zuchdi, Darmiyati. 2008. Humanisasi pendidikan. Jakarta: Bumi Aksara.

Zuriah, Nurul. 2015. Pendidikan Moral dan Budi Pekerti dalam Perspektif Perubahan. Jakarta: Bumi Aksara. 